\title{
THE FANTASY OF THE PHRASE "INJURY TO COMPETITION"
}

\author{
WILIIAM Simon*
}

Competition is universally regarded as indispensable in the public interest. The competitive system is so much a part of our democratic, free enterprise, form of government that no one has ever even whispered less than devotion to the theory of competition.

The prices of commodities throughout the civilized world are determined either by price fixing conspiracies, by government regulation, or by active competition among competing sellers. Price fixing conspiracies are all against the public interest, are opposed by the overwhelming majority of the American people, and are the prime target of the Sherman Act. The planned absence of competition requires the government to regulate the rates of public utilities. Only by prices determined through vigorous competition can government regulation of business be avoided, for if the law denies the people the benefits of active competition, the public can be protected against unreasonable prices only by government regulation. Regulation of prices is not effective without, and may be expected to be followed by, regulation of production. That is the end of the free enterprise system.

\section{The Issue: Promoting Compettrion v. Protecting Competitors}

The choice is between an economy regulated by fair, but vigorous, competition, and the ultimate government regulation of industry. The controversy is between those who believe in and support the philosophy of our basic antitrust law and those who, falsely professing admiration for the competitive system, seek to avoid the competitive effects of vigorous competition. They seek protection against competition by urging that the law require rigid pricing, thus prohibiting sellers from competing.

The antitrust laws are designed to protect the public interest against "injury to competition." The law protects competition-that is, the competitive system-and not individual competitors who are trying to avoid competition. But the rigid pricing advocates, in a psychological use of significant words, seek to treat "injury to competition" as synonymous with "injury to competitors."

The truth is that competition is incompatible with avoiding injury to competitors. In every competitive effort some competitor is always hurt. There cannot be real competition, which is nothing less than a contest between rivals for the business

* Member of the Illinois bar; member of the firm of Miller, Gorham, Wescott \& Adams, Chicago; formerly General Counsel, Senate Interstate and Foreign Commerce Committee, Subcommittee on Pricing Policies, 8oth Cong., 2d Sess. (1948), and 8Ist Cong., Ist Sess. (1949). 
of customers, without some competitors being injured. In the economic strata in which competitors are not injured there is no competition. The law cannot prevent injury to competitors without making competition illegal.

The art of semantics has frequently been used for ulterior purposes. Hitler talked about invading the Balkans to "protect" the people of Eastern Europe. Stalin speaks of "liberating" the Baltic States, shouts admiration for "democracy," and rants opposition to "American-Imperialism." In the same manner the advocates of rigid pricing and the exponents of uniform f.o.b. mill selling speak of preserving "competition."

Humpty-Dumpty was at least more candid when he said, "When I use a word, it means just what I choose it to mean, neither more nor less." Let those who seek only to protect competitors admit their hostility to vigorous competition.

II

\section{F.T.C. Prior Position on Competitrve Freight Absorption}

The Congress passed the Sherman Antitrust Act because it believed vigorous competition would bring consumers improved products at lower prices and thereby raise our standard of living. ${ }^{2}$ This philosophy of the Sherman Act is diametrically opposed to the arguments made in the courts in Federal Trade Commission pricing cases.

In the Cement Institute, ${ }^{3}$ Pittsburgh-Plus, ${ }^{4}$ Rigid Steel Conduit, ${ }^{5}$ and Standard $\mathrm{O}^{\mathrm{i}}{ }^{6}$ cases the Federal Trade Commission argued for rules of law under the Federal Trade Commission and Clayton Acts which, although not always necessary to the decision of those cases, would have the practical effect of requiring uniform f.o.b. mill pricing and denying sellers the right to meet competition in good faith.

In the Cement Institute case the Commission argued and the Court said, in spite of the express finding by both of the presence of a conspiracy, that it was not necessary to prove a conspiracy to find a pricing practice an unfair method of competition. The Commission also argued that the Clayton Act requires sellers to have "a uniform net factory price."

In its brief in the Rigid Steel Conduit case the Commission said that basing point pricing was illegal per se and that the knowing concurrent use of a pricing system by several sellers was an unfair method of competition. ${ }^{8}$ The Commission describes this as "conscious parallel action."

\footnotetext{
${ }^{2}$ Lewis Carroli, Through the Looking Glass.

2 Annual Report to the Prestdent, Council of Economic Advisers I5 $_{5}$ (I948).

${ }^{3}$ Federal Trade Comm'n v. Cement Institute, 333 U. S. 683 (1948).

- United States Steel Corp. v. Federal Trade Comm'n, Docket No. 6798 (C. C. A. 3 d I938).

¿Triangle Conduit \& Cable Co. v. Federal Trade Comm'n, x68 F. 2d I75 (C. C. A. 7th 1948), affd per curiam sub nom. Clayton Mark \& Co. v. Federal Trade Comm'n, 336 U. S. 956 (I949).

'Standard Oil Co. v. Federal Trade Comm'n, I73 F. 2d 210 (C. C. A. 7th 1949).

${ }^{7}$ Oral Argument on October 20, 1948, before the United States Supreme Court in Hearings before the Subcommittee of the Committee on Interstate and Foreign Commerce on Sen. Res. 24I, 8oth Cong., 2d Sess. 48 I (I948).

${ }^{8}$ Brief for Appellee, $168 \mathrm{~F} .2 \mathrm{~d} 175$ (C. C. A. 7 th 1948 ).

${ }^{\circ}$ FTC, Notice to Staff, IN Re: Commission Policy Toward Gegraphic Pricing Practices (Oct. 12, I948).
} 
The Commission argued in the Pittsburgh-Plus case that, even in the absence of conspiracy, freight absorption and phantom freight were each equally illegal. ${ }^{\mathbf{1 0}}$

The Commission has filed other complaints alleging that buyers located near a seller's plant have an economic right to buy at lower prices than their more distant competitors. ${ }^{11}$ One count of a complaint, which does not allege a conspiracy, attacks the validity of a uniform national delivered price, ${ }^{12}$ and a count in another complaint, which does not allege a conspiracy, attacks the validity of a uniform zone price. $^{13}$

The rules of law urged in those cases would deny sellers the right to compete in distant areas beyond the territory in which they have a freight advantage over their competitors.

\section{III}

\section{The Practical Economics of Price Competition}

It is urged that prohibiting competitive freight absorption will restore "price competition," eliminate conspiracies to fix identical prices, and promote competition at the fringe of each seller's natural freight advantage territory (the benefits of which will accrue to all customers through the requirement for a uniform net factory price).$^{14}$

Price competition is said to exist only when sellers each have different delivered prices. To accomplish this result it is urged that each seller have a uniform net factory price to all buyers. While the premise ignores entirely competition at the levels of service, quality, responsibility, and integrity, it is even fallacious to assume that competition based on price alone requires each seller to have different prices, for when one seller is denied the right to meet (and the Clayton Act denies him the right to beat) the lower price of his more favorably located competitor, he is denied the right to compete on the basis of price.

The Commission's theory of "conscious parallel action" is that the economic effect of identical prices achieved through a seller knowingly pricing his goods in the same manner as his competitor is the same as that of identical prices achieved through conspiracy and is hence equally illegal. ${ }^{15}$

When two sellers ask the same price for the same commodity it may well be the result of a conspiracy. But, it may also be the result of active competition. Identical prices alone prove nothing. Further inquiry is required to know whether the sellers are competing on the basis of price, or conspiring to avoid competition on the basis of price.

\footnotetext{
${ }^{10}$ Brief for Appellee, United States Steel Corp. v. Federal Trade Comm'n, Docket No. 6796 (C. C. A. $3 \mathrm{~d}$ 1938).

${ }_{11}$ Federal Trade Comm'n v. American Iron \& Steel Institute, Docket No. 5508; Federal Trade Comm'n v. Clay Sewer Pipe Ass'n, Docket No. 5484; Federal Trade Comm'n v. National Lead Co., Docket No. 5253.

${ }_{12}$ Federal Trade Comm'n v. Chain Institute, Docket No. 4878.

${ }^{13}$ Federal Trade Comm'n v. National Lead Co., Docket No. 5253.

14 Frank A. Fetter, The Masquerade of Monopoly (1931).

${ }^{15}$ See note 9 supra.
} 
Life magazine contains the proud boast of Macy's and Saks department stores that they follow conscious parallel action in their pricing. Saks wrote: "Our staff of shoppers watches Macy's and other stores for just such price competition. Each shopper is trained to telephone in as soon as she finds any item which appears to be selling at prices lower than ours so that we can immediately mark ours down." Macy's replied that it employs "8I comparison shoppers" who make more than 35,000 shoppings a week "in order to maintain our price policies."

When the price of a particular Arrow white shirt sells at precisely the same price at both Saks and Macy's-and at Gimbels and a dozen other New York department stores-there is no presumption of an absence of price competition. Such price behavior is even less suspect in the sale of a homogeneous commodity where buyers will not pay more to one seller than to another.

Conspiracies to fix identical prices are admittedly eliminated by prohibiting all identical prices. But when like prices result from vigorous competition they tend to a healthy economy. Only when those prices result from conspiracy, and thus eliminate competition, are they destructive of our competitive economy. We can not prohibit all competition in order to prevent some iniquitous activity which eliminates competition. To do so would be tantamount to burning down the house to get rid of the termites.

Students of economics usually point to commodity exchanges as examples of true competitive markets. A long term analysis of those markets shows that whenever there is a sharp break or a sharp rise in price on one commodity exchange, it is immediately followed by a similar movement on all other exchanges. A price decline in Chicago wheat will be followed, within a matter of minutes, by a similar movement on the Kansas City, Minneapolis, and all other grain markets. Analysis discloses not only parallel price movements between such markets, but a parallel price relationship between markets which rarely deviates to any appreciable extent.

Is the "conscious parallel action" in those markets year after year evidence of conspiracy? Obviously not. When wheat goes up in Chicago, the absence of a similar price movement in Minneapolis results in the buying of Minneapolis wheat for sale in Chicago. The time lag in market movements is only as long as is required for communication between those markets. The price relationship between markets is relatively constant at the freight rate between markets. The lower price is in the west where the grain is grown, and, as it moves east after harvest, higher prices prevail in that direction. When Chicago wheat sells above Kansas City wheat, in excess of the freight rate between those cities, traders buy in Kansas City and sell in Chicago.

Parallel market action in grains is a normal competitive phenomenon. Salesmen may, and frequently do, compete in the same manner. When a seller can invade a distant market and compete (not conspire) with his more favorably located competitor only by absorbing freight, he should be encouraged to do so.

${ }^{10}$ Jan. 3, 1949, p. 2, col. I. 
To separate competitive activity in the public interest from conspiratorial activity opposed to the public interest, is the function of the law enforcement agency. The Department of Justice, with an enviable record in the enforcement of the Sherman Act, does not seem to find any insurmountable difficulties in doing so.

The myth of competition at the fringes of each seller's monopoly area (under a required uniform net factory price) presupposes that the competing sellers are each located an equal distance from a large consuming market in which each desires to compete. But, when the fringe area is a lake, a prairie, or a mountain range, there is no competition at the fringe, or anywhere else. Each seller is thereby given a monopoly in the area in which he has a freight advantage over his competitors, with the public deprived of the benefits of competition.

Economic disruption, losses in plant investments, dislocation of industrial workers, and concentration of industry (adverse to the national defense program) would clearly result from required uniform f.o.b. mill pricing, as is shown by the Report of the Senate Interstate and Foreign Commerce Committee on Federal Trade Commission Pricing Policies. ${ }^{17}$

A Congressional inquiry followed the decisions of the Supreme Court in the Cement Institute case, and of the Seventh Circuit in the Rigid Steel Conduit case.

When the economic impact of required f.o.b. mill pricing was analyzed, there were virtually no supporters for the view that the producer should be required to sell his goods for a uniform price at the factory door.

Five Congressional committees, including the Patman Committee, heard a total of 160 witnesses testify on this subject. ${ }^{18}$ Yet, only seven witnesses, four Federal Trade Commission employees, and three college professors-but not a single businessman-testified in support of the philosophy that sellers should not be permitted to absorb freight to compete in distant markets. ${ }^{10}$

\section{IV}

\section{F.T.C. Current Position on Competitive Freight Absorption}

When the Commission's position in the above cases was exposed to public scrutiny, the Commissioners themselves disavowed that philosophy and appeared to shift their reliance to members of their staff holding more orthodox views. ${ }^{20}$

${ }^{27}$ Sen. Dod. No. 27, 8rst Cong., rst Sess. (1949).

${ }^{18}$ Hearings before Senate Committee on Interstate and Foreign Commerce on Sen. Res. 241, 80th Cong., 2d Sess. (1948), 109 witnesses; Hearings before Senate Committee on Interstate and Foreign Commerce on S. 236, 8Ist Cong., Ist Sess. (1949), 21 witnesses; Hearings before Senate Committee on the Judiciary on $S$. 10o8, 81st Cong., Ist Sess. (1949), 13 witnesses; Hearings before Houtse Committee on the Judiciary on S. 1008, 81st Cong., Ist Sess. (1949), 2 witnesses; and Patman Hearings, "Small Business Objections to Basing Point Legislation," 15 witnesses. (This computation includes some duplication.)

${ }^{19}$ Walter B. Wooden (F.T.C. Attorney), Everette MacIntyre (F.T.C. Attorney), Eugene W. Burr (former F.T.C. Attorney), William S. Johnson (F.T.C. Economist), Vernon A. Mund (Professor, University of Washington), Fritz Machlup (Professor, Johns Hopkins University), and Walter Adams (Professor, Michigan State College).

${ }^{20}$ Statement of Commissioner E. L. Davis, in Hearings before Committee on Interstate and Foreign Commerce on S. 236, 8Ist Cong., Ist Sess. 22-3I (1949); written answers of Commissioner E. L. Davis 
The Commission's view now officially reported to the Congress is that freight absorption was never illegal under the Federal Trade Commission Act, in the absence of conspiracy, and that the Cement and Conduit cases apply only to conspiracy situations. ${ }^{21}$

In July, 1949, the Commission, although it denied a motion to modify its order in the Conduit case, in effect did modify the order, for it said: "The Commission does not consider that the order in its present form prohibits the independent practice of freight absorption or selling at delivered prices by individual sellers." It appeared reluctant, however, wholly to abandon its doctrine of "conscious parallel action," for, in apparent contradiction of the above statement, it added that the order does prohibit the use of the "basing-point, delivered price system ... when done, as stated in the order, for the purpose or with the effect of systematically matching delivered price quotations."22

The key words there are "or with the effect." The effect of meeting a competitor's price may be the same whether done by conspiracy or through vigorous competition. Thus the order seems directed, at least in part, to competitive practices individually pursued. Conceivably the Commission may justify this position on the ground that it is necessary to prohibit individual conduct, formerly carried on by conspiracy, in order to dissipate the effects of the conspiracy. The point was suggested to the Supreme Court in the Conduit case, but was not decided when the Court divided four to four and did not file an opinion.

The Commission's position appears, however, to continue to be confused. In the pending case against the steel industry involving freight absorption, the Commission's trial attorney, an Associate Chief Trial Counsel, entered into a settlement agreement which would permit some freight absorption. On December 5, 1949, the Commission made public the settlement agreement and a memorandum of its trial counsel urging that it be approved by the Commission. At the same time it released a memorandum from the trial counsel's superior, the Chief Trial Counsel, urging the Commission to reject the settlement. As this is written the Commission has not acted.

\section{$\mathrm{V}$ \\ What Is Competimton?}

It has often been said that competition is worth what it costs. If we are to have competition we cannot restrict its normal effects. The effect on an individual businessman may be the same whether he is driven to bankruptcy through vigorous, but fair, competition, or through à conspiracy to drive him out of business. But only in the latter case is there any injury to competition. In the former case the

(concurred in by Commissioners Ferguson and Ayres) to questions submitted by Senator E. C. Johnson, id. at $268-278$.

21 Ibid.

22 Rigid Steel Conduit Mfgrs., CCH Trade Reg. Serv. \$14 (Docket No. 4452, 1949). 
effect on the competitor is the incidental effect of giving the public the benefits of vigorous competition.

Since admiration for competition appears to be universal, let us inquire into its meaning. The dictionary defines it as, "endeavoring to gain what another is endeavoring to gain," "common strife," "a contest between rivals," "a match between contestants," or "the effort of two parties, acting independently to secure the custom of a third by offering the most favorable terms." ${ }^{23}$

Competition for business is no less a contest between rivals than a baseball game. In either contest one competitor always wins while another always loses. As long as the rules of the game are fair, and the contest is conducted according to those rules, there is a bona fide contest between rivals. In any such contest one contestant will always get hurt. To require a ball game always to end in a tie score would be to destroy any vestige of a contest. To prohibit injury to business competitors is to prohibit competition among them. ${ }^{23^{a}}$

\section{VI}

The Conflict between the Phrlosophy of the Sherman Act and Rigid Pricing

Rigidity of price is used to prove the absence of competition in cases charging a violation of the Sherman or Federal Trade Commission Acts. On the other hand, flexibility of price is almost certain to result in violation of the Robinson-Patman amendment to the Clayton Act.

Sellers may absorb freight to compete in distant markets, if they walk the narrow path between charges of conspiracy to fix prices, established through evidence of rigid prices, and charges of illegal price discrimination, established through evidence of flexible prices.

The use of circumstantial evidence is, of course, fundamental in proof of conspiracy. While mere identity of price is admissible evidence under a conspiracy charge, a finding of conspiracy has never been founded on a mere showing of identical prices.

But a businessman may, nevertheless, be found to have participated in a conspiracy without any intention to do so. The Interstate Circuit, ${ }^{24}$ American Tobacco, ${ }^{25}$ and Masonite ${ }^{26}$ cases seem to hold that a conspiracy may be proved by evidence of adherence, over a period of time, to practices also rigidly followed by competitors, under circumstances indicating the absence of a purpose to compete. It is not necessary to show that the parties communicated with one another, if an understanding can be inferred from their conduct.

Circumstantial evidence-for example, that the seller did not adhere to any particular pricing pattern-is also admissible to disprove a charge of conspiracy. The

${ }^{23}$ Webster's New International Dictionary (2d ed. unabridged).

${ }^{23 a}$ For an excellent discussion of the difference between injury to competition and injury to a competitor see Statement of House Managers accompanying Conference Report on S. roo8, filed October 13, I949 (House Report No. 1422).

${ }_{24}$ Interstate Circuit, Inc. v. United States, 306 U. S. 208 (r939).

${ }^{25}$ American Tobacco Company v. United States, 328 U. S. 781 (1946).

${ }^{26}$ United States v. Masonite Corporation, 316 U. S. 265 (I942). 
Commission has on occasion determined whether to file a conspiracy complaint by an arrangement with the proposed respondents for a spot check of their invoices. Rigid adherence to price lists during the selected period is considered to indicate the likelihood of a price fixing agreement. However, large scale deviations are generally regarded as disproving any price fixing conspiracy. Such a test, applied. by the Circuit Court of Appeals for the First Circuit, recently resulted in a reversal of the Commission in the Tag case. ${ }^{27}$

But a flexible price structure which proves the absence of a price fixing conspiracy, may, as indicated above, lead to a charge of illegal price discrimination, for any departure from the published price list may well result in a discrimination. And where there is a discrimination, the Commission is prone to find that it "may" injure competition.

It is not surprising that the Secretary of Commerce recently told the Congress that many businessmen feel they are faced with the choice of violating the Sherman Act by charging uniform delivered prices, or violating the Patman Act by charging different prices to different customers. ${ }^{28}$ And even the Commission's Chief Economist has publicly said that the philosophy of the Sherman Act appears to be in conflict with the philosophy of the Robinson-Patman Act. ${ }^{29}$

\section{VII}

\section{Is Meeting a Competitor's Price in Good Faith Wicked?}

Section 2(a) of the Clayton Act, as amended by the Robinson-Patman Act, makes price differences illegal when they have the specified adverse effect on competition and are not within the exemptions of the statute. Section 2(b) provides that whenever the Commission has shown a price discrimination, the seller may rebut the prima facie case thus made out by showing that he made the lower price in good faith to meet competition.

Prior to the recent decision of the Court of Appeals for the Seventh Circuit in the Standard $\mathrm{Oil}^{30}$ case, it was generally assumed that an affirmative showing of good faith meeting of competition was a full defense to a charge of price discrimination. The Court there held, however, that Section 2(b) is purely procedural; that the Commission makes out a prima facie case by showing a difference in price; that a showing of good faith meeting of competition does no more than shift the burden back to the Commission; and that it can then establish illegality by showing injury to competition.

For the first time, good faith meeting of competition was there ruled out as a

${ }^{27}$ Tag Mfrs. Institute v. Federal Trade Comm'n, I74 F. $2 d 452$ (C. C. A. Ist 1949).

${ }^{28}$ Statement of Charles Sawyer, in Hearings before Committee on Interstate and Foreign Commerce on S. 236 , supra note 20 , at 5,6 .

${ }^{20}$ Corwin D. Edwards, F.T.C. Economist, before the Second 1948 Economic Institute, Chamber of Commerce of the United States, Dec. 9 and Io, 1948, printed transcript p. ro8.

${ }^{30}$ Standard Oil Co. v. Federal Trade Comm'n, I73 F. 2d 210 (C. C. A. 7th r949). 
defense to a charge of price discrimination. The case is now pending on petition for certiorari to the Supreme Court. ${ }^{31}$

Apart from the order in that case, the record shows that the Commission is of the view that the law should permit good faith meeting of competition to be a defense to a charge of price discrimination. ${ }^{32}$ The Department of Justice takes the position that this is in fact now the law. ${ }^{33}$

The Standard Oil case involved a price difference to tank car buyers, operating their own bulk storage facilities and delivery trucks (commonly called wholesalers), over the price to tank wagon (truck) buyers (commonly called retailers). There was no charge that Standard sold to one tank car buyer at a lower price than to any other tank car buyer, or at a price lower than such buyer could lawfully have purchased like gasoline from a competitor of Standard. Nor was there any charge that Standard sold to one tank wagon buyer at a lower price than it sold to any other tank wagon buyer.

One of Standard's tank car customers, Ned's, resold gasoline only through its own retail service stations and was a persistent price cutter. Another, Citron, in part followed that practice. The others were not price cutters. All except Ned's resold gasoline purchased from Standard both to other retail station operators and through stations owned by them. The Commission found this price cutting resulted in an injury to competition at the retail level. On this finding it was held that the foregoing difference in price constituted an illegal price discrimination.

The Circuit Court said, however ${ }^{\mathbf{3 4}}$

There is substantial evidence in the record, and we think it may be assumed to be conclusive, to the effect that the petitioner [Standard] made its low price to Ned's, Citron, Wayne and Stikeman in good faith to meet the lower price of a competitor.

Standard's wholesale customers did not receive preferential treatment over other Detroit wholesalers. It would appear that the injury to retail gasoline dealers would not have been different had Ned's purchased its gasoline from a major supplier competitor of Standard, and, therefore, Standard's good faith meeting of competition was not the direct cause of the injury at the retail level.

Indeed, it is difficult to conceive of a situation where competition will be injured or lessened by a seller in good faith meeting the lower price of a competitor. When sellers are actually competing in good faith, how can competition be injured?

The reasoning of the Standard Oil decision is based on the premise, believed to be a fallacious fantasy, that injury to competition and injury to competitors are synonymous. The Court said the evidence of Standard's good faith competition "may be assumed to be conclusive," presumably because Standard's "price-cutting" wholesalers could have lawfully purchased the same product at the same or a lower

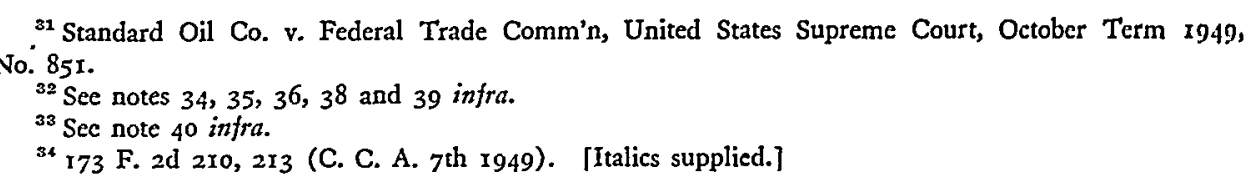


price from one or more of Standard's competitors. The effect on competition at the retail level would not have been different had those "price-cutters" purchased from another supplier which could lawfully sell to them at that price because it sold only to wholesalers in that area. How can the good faith meeting of a competitive price, which competitors are lawfully offering to the seller's customers, be said to injure competition, regardless of what it does to competitors?

Retail competition was not hurt by what Standard did. Any injury resulted from the fact that Ned's, because it owned its own bulk storage plant and distribution facilities, was able to buy in tank car quantities at wholesale prices.

Standard's wholesale customers could continue to undersell the prevailing service station price by purchasing from Standard's competitors, who sell only in tank car quantities, just as others now do. Standard's difficulty arose from the fact it sold to both wholesalers and retailers in the same area, even though it sold to each class at or above the prevailing price to that class of customer.

During the oral argument of the Standard Oil case, the Court asked Commission counsel if a discrimination could ever be justified under Section $2(\mathrm{~b})$, as there would always be some injury to someone in every discrimination. The reply was that Congress intended the defense of good faith meeting of competition to apply when the charge is injury to competition at the seller's level, but not when there is a claim of injury to competition at the buyer's level. ${ }^{35}$

In a complaint against General Foods Corporation there is a charge of geographic price discrimination where it is affirmatively alleged that a lower price made on the west coast was available in that area to all buyers alike, "wholesale grocers, direct buying chains, and independent retail grocers." That complaint even alleges that the seller took precautions to insure that the lower price not be available to anyone in areas where it was not available to all. ${ }^{36}$

Those who believe in, and whose obligation it is to promote, the competitive system, have urged that good faith meeting of competition be a full defense to a charge of price discrimination.

Let us examine the position of the Federal Trade Commission itself. Its October, x948, "Statement of Policy" says that the Clayton Act "prohibits price discriminations which injure or prevent competition, unless either the price differences can be justified by differences in cost or else the price reductions have been made in good faith to meet the equally low prices of competitors." By way of a footnote, it apologetically added that it was seeking to "ascertain" in the pending Standard Oil case whether this is so where there was an injury to buyers. ${ }^{37}$

In February, 1949, the Commissioners advised a Senate Committee that meeting competition in good faith should be a defense to a charge of price discrimination and that "in general the policy of the law should not discourage active competition by preventing the meeting of competition in good faith."38

${ }^{\text {as }}$ Oral argument, pp. 53, 54, 173 F. 2d 210 (C. C. A. 7th 1949).

${ }^{30}$ General Foods Corporation, Federal Trade Comm'n Docket No. 5675 (July 7, 1949).

${ }^{87}$ See note 9 supra.

${ }^{38}$ Hearings, supra note 20 , at $274,275$. 
Less than three weeks after the Standard Oil decision, an official Commission spokesman told a Senate Committee that it had no objection to a permanent change in the law to make the meeting of an equally low price of a competitor in good faith a full defense in price discrimination cases. ${ }^{30}$

The Congressional Record discloses that the O'Mahoney Bill, ${ }^{40}$ in a form clearly making good faith meeting of competition a full defense to a charge of price discrimination, was drawn by members of the Commission's staff. ${ }^{41}$

The strength of the Commission's view was tested when it was asked to comment on the Kefauver amendment to that bill, limiting the defense of good faith meeting of competition. This was embarrassing for the Commission because Senator Kefauver is one of its staunchest supporters. Yet on June 9, r949, the Commission wrote the Congress that, ". . . all of the Commissioners believe that on balance it would be preferable to make the good faith meeting of competition a complete defense." ${ }^{\prime 2}$

The office of the Attorney General has consistently supported good faith meeting of competition as a complete defense. Shortly before the circuit court decision, the Department of Justice advised a Senate Committee that the present law "permits sellers to justify otherwise forbidden price discriminations on the ground that lower prices to one set of buyers were made in good faith to meet the prices of a competitor." ${ }^{\text {33 }}$ The Department of Justice later recommended "deletion of the parenthetical phrases in Sections 2 and 3, the so-called Kefauver Amendment. The effect of these phrases is to eliminate the defense that acts of freight absorption or price discrimination, charged to be a violation of the Clayton Act, were undertaken in good faith in meeting competition where the effect of such acts would be to substantially lessen competition." ${ }^{44}$ After the House Judiciary Committee followed that recommendation, the bill was expressly approved by both the Attorney General and the White House. ${ }^{45}$

In their December, I948 report to the President, his Council of Economic Advisers criticized the Patman Act for prohibiting business practices long regarded as legitimate features of hard rivalry for business. ${ }^{46}$

One of its members recently told the House Judiciary Committee that the Council of Economic Advisers had proposed corrective legislation because they felt "the law

${ }^{30}$ Hearings before the Senate Comnittec on the Tudiciary on S. 1008, 81st Cong., Ist Sess. 72 (1949).

'0 Sec. 3 of S. 1974 (later substituted for S. 1008), 81st Cong. (1949).

${ }^{41} 95$ Cong. Rec. II 49I-II 492 (Aug. II, 1949).

« Letter dated June 9, I949, from E. L. Davis, Acting Chairman, Federal Trade Commission, to Francis E. Walter, in Hearings before House Committee on the Judiciary on S. 1008, 81st Cong., 1st Sess. 6I (1949).

${ }^{43}$ Hearings, supra note 20 , at 320 .

"Testimony of Herbert A. Bergson, Assistant Attorney General in Charge of the Antitrust Division, Hearings, stupra note $4 \mathrm{r}$, at 12.

${ }^{45} 95$ Cong. Rec. 9164 (July 6, 1949).

${ }^{46}$ See note 2 supra. 
and the Commission had stepped over the line between unfair methods and those which are the essence of vigorous competition." ${ }^{\prime 7}$

He asked the Congress: "Is it a desirable national policy to tie the hands of the big competitor and thereby make it easier for the small business man to survive?"

And he gave this answer: ${ }^{48}$

I have no doubt that Woodrow Wilson and his predecessors would have furiously protested any such proposal. Today, many supporters of the antitrust policy will give hesitant answers. My own is that there is a heavy burden of proof upon him who would temper the storms of competition for the lamb in this manner. He must do more than argue for stability of business. He must make an exceedingly strong case that his proposal will not, by depriving competition of its vigor, deny the people those benefits of larger production, lower costs and prices, and improved standards of living which the Sherman Act was designed to promote.

Senate Bill 1008, as reported out of conference on October I3, I949, would make lawful the good faith meeting of a competitor's equally low price, as well as competitive freight absorption, subject to the limitation that the bill not make lawful any combination, conspiracy, or unlawful agreement; or any monopolistic, deceptive, fraudulent, or oppressive practice. The House of Representatives approved the Report October I4, r949.

\section{VIII}

\section{The Bastc Conflict Involves Our Free Enterprise System}

The conflict is between those who, while paying lip service to competition, in fact seek protection from it, and those, on the other hand, who whole-heartedly support our antitrust philosophy.

The economic issue is whether we are to deprive 145 million people of the benefits of vigorous competition in order to insure financial stability to the few who are either unable, or feel they are unable, to withstand the rigors of vigorous, but fair, competition.

A member of the Federal Trade Commission recently told a Senate Committee: ${ }^{49}$

I yield to none in my desire to see a free competitive economy in the United States survive and to preserve to industry and our people the prosperity and freedom we have achieved under the capitalistic system. Free competitive enterprise is the foundation of our capitalistic system. Whatever weakens that foundation weakens the life-blood of industry and the capitalistic system. ... It is the duty of the Commission to seek the interpretation of important legal points at issue and to promote and foster competition in industry.

Yet the Commission, which considers its duty to be to "promote and foster com-

17 Testimony of John D. Clark, in Hearings before Subcommittee on Monopoly Power of the House Committee on the Judiciary, 8rst Cong., Ist Sess. Ir4 (I949).

${ }^{18}$ Ibid.

${ }^{10}$ Commissioner E. L. Davis, in Hearings, stpra note 20, at 26. (Italics supplied.) 
petition," has entered an order finding illegal a competitive practice which it describes as follows: $:^{50}$

The competitive effects of respondent's discriminatory prices on other manufacturers of controls are persuasively indicated by its own arguments that its discriminatory prices were made for the purpose of meeting competition. These arguments show that respondent's discriminatory prices were made to retain the business of certain customers or to secure the business of others and that they were largely successful in doing so. To the extent that business is held by or diverted to respondent from its competitors by its discriminatory prices and unfair practices, competition has been adversely affected within the meaning of the law.

To reach the conclusion that "competition has been adversely affected" to "the extent that business is held by" a seller who varies his price "to retain the business of certain customers," is certainly giving the word competition a meaning not found in the dictionary.

That conclusion also eliminates the good faith meeting of competition, for proof of good faith meeting of competition automatically proves a price to try to hold business, or to divert business, from a competitor. This is apparently considered by some to be proof of an adverse effect on competition.

We are here discussing good faith competition. The emphasis is on "good faith." Predatory practices and strong arm methods to drive competitors out of business are never in good faith. Selling below cost or local price cutting in one area, offset by profits in other areas, for the purpose of driving competitors in that area out of business to gain a monopoly for the aggressor, is certainly not within the law.

Woodrow Wilson said he took off his hat to the businessman who, by selling a better product at a lower price, was able to run his competitor out of business. There are many today who would brand him a "tool of the monopolist," for such a statement. ${ }^{51}$

Competent, aggressive, and energetic small businessmen find they are well able to compete with their larger competitors. The financial disadvantages of smallness can be, and frequently are, more than offset by the advantages of service, friendliness, and personal contact. The independent merchant who exploits his advantages of personal supervision is tough competition for his larger competitors.

We must make a choice between soft competition and hard, vigorous competition; between promoting competition and protecting competitors; between forcing the public to pay higher prices to guarantee profits to the marginal and inefficient merchants and giving the public the benefits of competition; between prohibiting aggressive competition and protecting those who are either unwilling or unable to engage in aggressive competition. We cannot have both.

\footnotetext{
${ }^{60}$ Federal Trade Comm'n v. Minneapolis-Honeywell Regulator Co., Docket No. 4920, order entered Jan. 14, 1948. (Italics supplied.)

${ }^{61}$ See note 2 supra.
} 
There is no choice if we are to maintain a democratic free enterprise system.

If we are to succeed in outlawing price fixing conspiracies and avoid government regulation of industry, we must permit the price of goods to be determined through open and vigorous competition. To say that restriction of vigorous competition is the road to statism, is to invite all sorts of epitaphs. But the Federal Trade Commission has itself described the choice as being between competition and collectivism, saying: ${ }^{: 2}$

Either this country is going down the road to collectivism, or it must stand and fight for competition as the protector of all that is embodied in free enterprise.

And the Commission has described the relationship between democracy and the competitive system as: $:^{53}$

The capitalist system of free initiative is not immortal, but is capable of dying and of dragging down with it the system of democratic government.

It is not possible to give the public the benefits of lower prices resulting from competition and at the same time protect merchants who are not willing to compete against the normal effects of competition.

If our free enterprise, democratic form of government is to survive, those responsible for government policy must stop paying mere lip service to the competitive theory of the Sherman Act.

62 FTC, Report on THE MERger MOVEMENT 69 (1948). While directed at the absence of competition resulting from mergers, the remarks apply equally to the loss of competition.

${ }^{3}$ Ibid. 